\title{
Focal mechanism and source determination of the Padang Lawas earthquake april 30, 2020, using moment tensor inversion
}

\author{
Retno Agung Prasetyo ${ }^{1 *}$, Supriyanto Rohadi ${ }^{1}$, Nelly Florida Riama ${ }^{1}$, Yusuf Hadi Perdana ${ }^{1}$, Rahmat Setyo \\ Yuliatmoko $^{1}$, Lewi Ristiyono ${ }^{2}$ and Marzuki Sinambela ${ }^{2}$ \\ ${ }^{1}$ Research and Development Centre, Meteorological Climatology and Geophysical Agency (BMKG), Jl. Angkasa I No.2 Kemayoran, \\ Jakarta Pusat, 10610, Indonesia \\ ${ }^{2}$ Meteorological, Climatological And Geophysical Regional I (BBMKG Wilayah I), Medan, 20131, Indonesia
}

\begin{abstract}
The earthquake focal mechanism is one of the essential parameters in understanding the characteristics of an earthquake source. For example, the earthquake mainshock at the Padang Lawas Regency and South Tapanuli Regency on April 30, 2020, caused some damage to houses, schools, and mosques, especially in the South Tapanuli Regency. BMKG released the first information that the earthquake was 1.17N, 99.53E, 24 kilometers northwest of Padang Lawas, North Sumatra province, at a depth of 10 kilometers, Thursday (30/4/2020) at 15.20.25 Local Time with a magnitude of 5.6. The purpose of this study is to determine the focal mechanism of the Padang Lawas earthquake mainshock on April 30, 2021, and determine the fault nodal plane that best suits local tectonic conditions. We used the moment tensor inversion method by using waveform velocity data from the BMKG mini regional station seismic network installed in 2019 and close to the epicenter, namely TTSM, PLSM, LTSM, and RRSI. We also used the velocity model from AK135. In this study, we applied the filter technique using a Butterworth bandpass filter with a lower limit of $0.05 \mathrm{~Hz}$, an upper limit of $0.10 \mathrm{~Hz}$, and a cut frequency of $0.13 \mathrm{~Hz}$. The result of the moment tensor inversion shows the variance of the observation and calculation data is 0.3824 . The earthquake source parameters show that the Nodal I plane with strike/dip/slip values is 100.1/88.3/7.5 and the Nodal II plane with strike/dip/slip values is 9.9/82.5/178.3. The value of Seismic Moment (Mo) is $0.4653 \mathrm{E}+17 \mathrm{Nm}$ or $\mathrm{Mw} 5$. Based on the distribution of aftershocks and the mechanism pattern of the Tapanuli earthquake source on April 30, 2020, it is consistent with the nodal plane II. The mechanism is in the form of a strike-slip fault and corresponds to the movement mechanism of the Sumatran fault system in the Toru segment. Therefore, the tectonic conditions in the southern part of Padang Lawas Regency and South Tapanuli Regency are classified as active. Thus, the government and society need to be aware and make mitigation efforts against the impact of the next earthquake in the future.
\end{abstract}

\section{Introduction}

Sumatra is a part of Indonesia that has been frequently hit by significant and destructive earthquakes in the last two decades. The major earthquake in Sumatra was sourced from tectonic activity in the subduction zone in the west of Sumatra under the Indian Ocean and tectonic activity from the Sumatra Fault System (SFZ), which is located on the mainland of the island of Sumatra.

SFZ consists of several segments whose slip rate is known [1]. The SFZ is located extending from Banda Aceh to the Sunda Lampung Strait for $1900 \mathrm{~km}$ [2]. The SFZ crosses several cities in Sumatra and can cause a large earthquake in each fault segment.

Several cities in the southern region of North Sumatra, namely Tarutung, Padang Sidempuan, Sipirok, Padang Lawas, and Mandailing Natal, are trajectories of several SFZ segments. This condition affects earthquake activity which often occurs and has an impact on these areas. One of the significant earthquakes that hit this area occurred on April 30, 2020, with a magnitude of 5.6 at 15.20.25 WIB and the epicenter coordinates of $1.17^{\circ}$ North, 99.53 East, at a distance of 24 kilometers
Northwest of Padanglawas Regency with a hypocenter depth of $10 \mathrm{Km}$. This earthquake caused damage in the South Tapanuli area, which damaged two places of worship, an elementary school building, and four houses in Aek Libung, Sayur Matinggi, South Tapanuli. There are no scientific publications related to these earthquake focal mechanisms. Is this earthquake-related to the Toru segment or Angkola or Barumun, or another local fault activity?

Analysis of the mechanism of the Padanglawas earthquake source is needed to obtain information on the fault plane following the surrounding tectonic conditions. Furthermore, knowing the fault plane can be used as a reference for mitigation efforts against earthquake hazards in earthquake-affected areas. Map of these research areas and the mainshock location can be seen in Figure 1.

\footnotetext{
*Corresponding author: prasetyo.agung@bmkg.go.id
} 


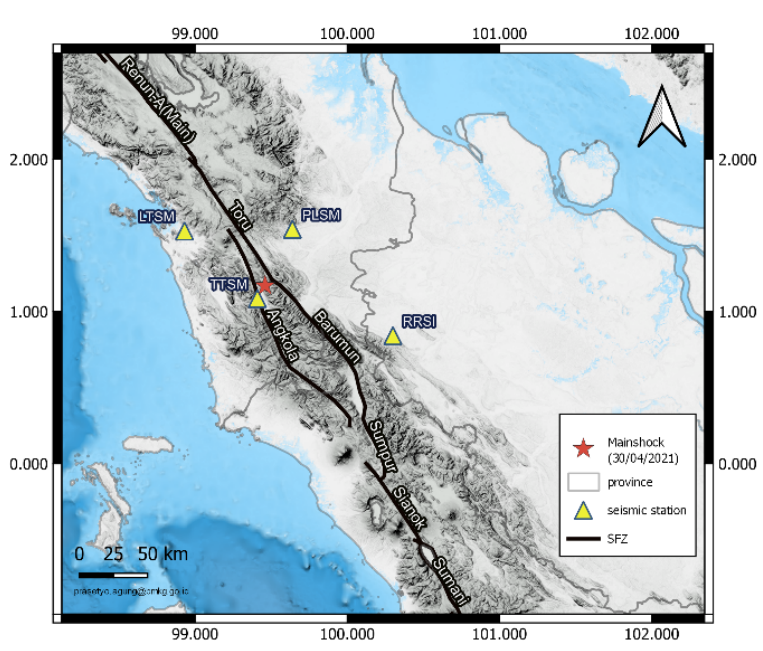

Fig. 1. Location of EQ Mainshock (red star) and BMKG seismic station (yellow triangle) that used, also tectonic fault (black line) layout at this research area.

\section{Data}

The data used in this study is the waveform recording of the Padanglawas earthquake on April 30, 2020, which was obtained from the BMKG seismic station closest to the epicenter location, namely TTSM, PLSM, LTSM, and RSSI. A complete description of the BMKG seismic station used in this study is shown in Table 1. All of these seismic stations were installed in 2019.

Table 1. Metadata of seismic stations used in the study.

\begin{tabular}{|c|c|c|c|c|c|}
\hline Station & Digitizer & Sensor & $\begin{array}{c}\text { Lat } \\
(\mathbf{D e g})\end{array}$ & $\begin{array}{c}\text { Long } \\
(\mathbf{D e g})\end{array}$ & $\begin{array}{c}\text { Altitude } \\
(\mathbf{m})\end{array}$ \\
\hline TTSM & Centaur & $\begin{array}{c}\text { Trillium- } \\
\text { Compact }\end{array}$ & 1.085 & 99.41 & 173 \\
\hline PLSM & Centaur & $\begin{array}{c}\text { Trillium- } \\
\text { Compact }\end{array}$ & 1.540 & 99.64 & 88 \\
\hline RRSI & Centaur & $\begin{array}{c}\text { Trillium } \\
\text { Horizon }\end{array}$ & 0.841 & 100.3 & 90 \\
\hline LTSM & Centaur & $\begin{array}{l}\text { Trillium- } \\
\text { Compact }\end{array}$ & 1.529 & 98.93 & 5 \\
\hline
\end{tabular}

Earthquake recording data from several stations closest to the earthquake source used in this study can be seen in Figure 2. The nearest station to the epicenter is TTSM, which is $12 \mathrm{~km}$, and the farthest is RRSI, which is $100 \mathrm{~km}$.

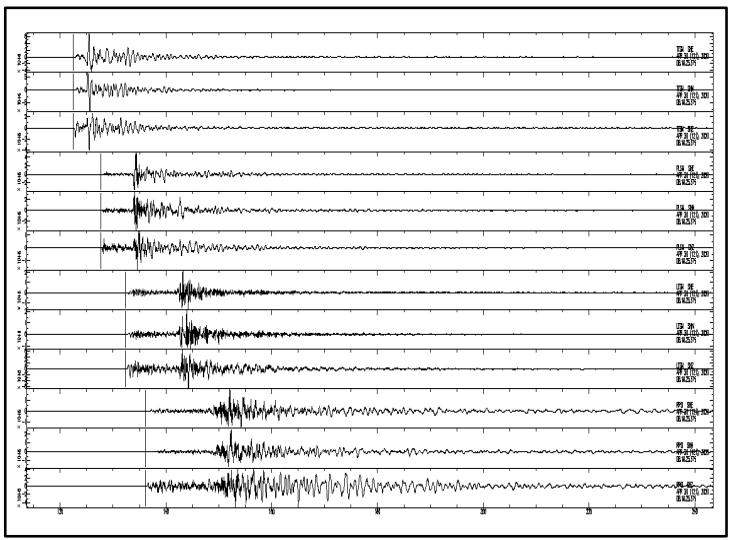

Fig. 2. Waveform seismogram (count unit) at station TTSM, PLSM, LTSM, and RRSI, which is each station is 3 component. Software using SAC [3].

\section{Method}

The method used in this study is the moment tensor inversion with a double couple approach [4]. We use SAC for data processing, so converting from miniseed data into SAC format is necessary. The velocity structure AK135 was used in this study. The filter uses the Butterworth bandpass filter method with a limit of $0.05-0.1 \mathrm{~Hz}$ and a cut frequency of $0.13 \mathrm{~Hz}$. We removed the instrument response during pre-processing steps by deconvolution of the response file for each seismometer in the SAC code. The moment tensor inversion process can be seen in Figure 3 below:

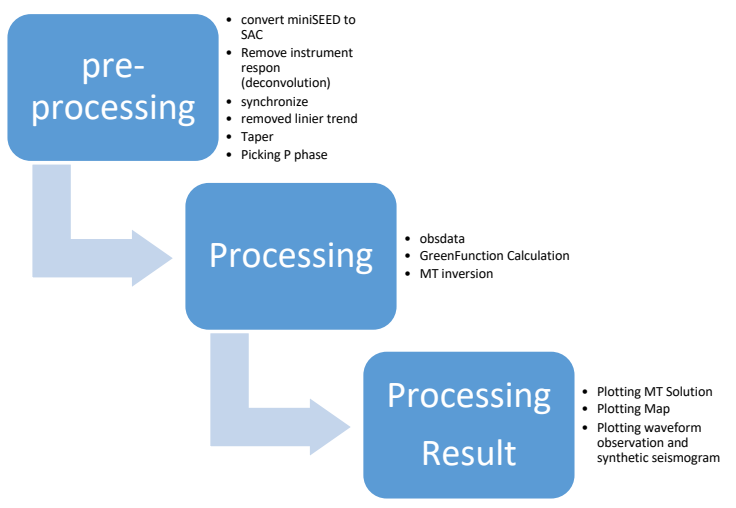

Fig. 3. Diagram processing of the moment tensor inversion

We used moment tensor inversion code from Yagi. This method provides a reliable technique to estimate the moment tensor solutions for moderate earthquakes [5]. In the processing stage, the obsdata, according to Figure 2, contains a description of the data that will be processed into an observation signal which includes the station name data and station components, the seismograph data type used is velocity, the signal duration starts from 5 seconds before $\mathrm{P}$, and the total signal duration is 120 seconds, the period of the sampling time used is 0.5 . The type of output signal is displacement.

\section{Result and discussion}

The result of the moment tensor inversion shows the variance of the observation and calculation data is 0.3824 . The earthquake source parameters show that the Nodal I with strike/dip/slip values is 100.11/88.33/7.53 and the Nodal II with strike/dip/slip values is 9.89/82.47/178.31. The value of Seismic Moment (Mo) is $0.4653 \mathrm{E}+17 \mathrm{Nm}$ or Mw 5.04 .

Based on the location of the main earthquake, which is near the end of the Renun segment and Angkola segment, and the area of the dominant aftershock distribution being on the southeast side of the main earthquake epicenter, the nodal plane II is more suitable as a fault plane parameter. Furthermore, these results can be strengthened by analysis of the direction of compression and dilation. The Sumatran fault mechanism is dextral so that the nodal plane II is more suitable. 
We also compare the focal mechanism resulting from the moment tensor inversion with the focal mechanism from the calculation of the initial polarity of the $\mathrm{P}$ wave using the first motion module [6] in Seiscomp3. The focal mechanism results from the first motion analysis showed NP1: $95 / 80 / 2$ and NP2: 4/88/170.

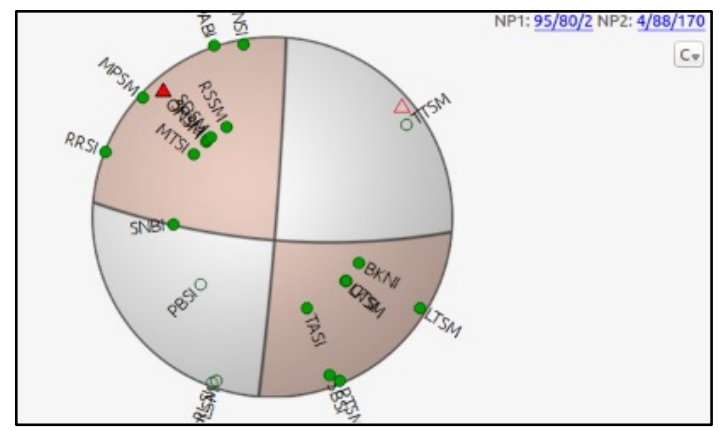

Fig. 4. Output from first motion analysis show the focal mechanism of mainshock April 30, 2020. Compression (white) and Tension (brown).

The results of the comparison of the focal mechanism data processing show a similar focal mechanism pattern between the moment tensor inversion results in Figure 5 and the First motion polarity in Figure 4. Furthermore this technique add strong confidence about the mechanism of the main earthquake on April 30, 2020 which is slightly different when compared to the historical map of the focal mechanism of earthquakes around the Sumatran fault [7].

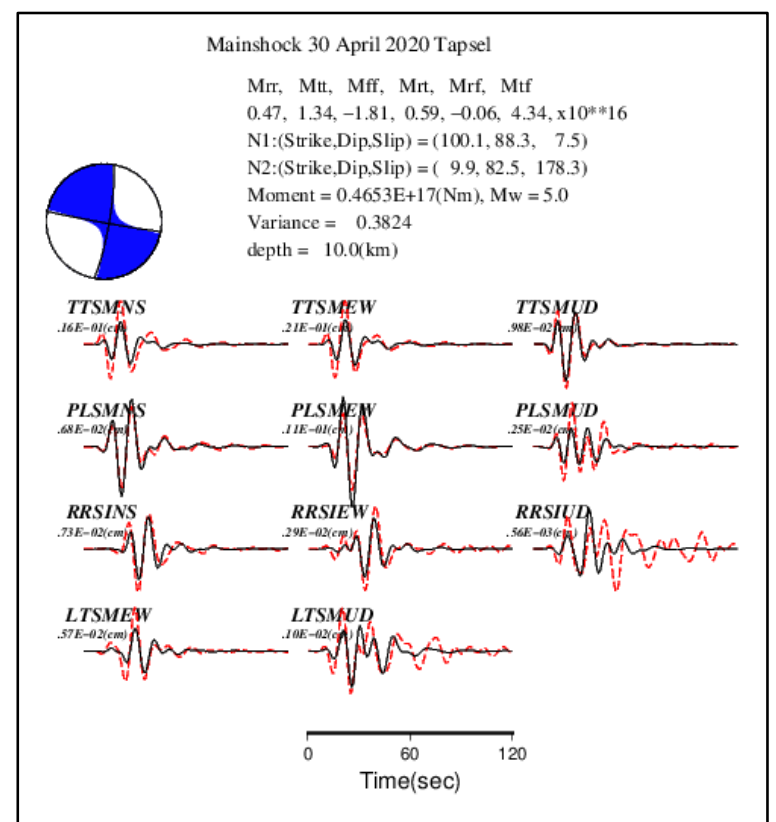

Fig. 5. Output from the moment tensor inversion show the mechanism, source parameter, and the fitting waveform between synthetic (red line) and observation data (black line).

Based on Figure 5, it can be seen that the fitting of observation and calculation data is suitable, especially in the low-frequency signal pattern is reasonable for Magnitude greater than 5 [8]. On the other hand, the signal pattern with a reasonably high amplitude indicates a displacement due to earthquake energy released in seismic waves.

BMKG informed that the source of the Padanglawas earthquake on April 30,2020, was the result of the Toru Fault activity. The active fault mapping study based on [2] was then explicitly detailed in the Tapanuli area by [1], namely the Angkola Fault and Toru Fault split into several smaller segments. Toru has a slip rate of $9.3 \pm 1.8$ $\mathrm{mm} /$ year, and Angkola has a slip rate of $4-5 \mathrm{~mm} /$ year [9]. Therefore, the potential for earthquakes in the study area is still relatively high, and earthquake mitigation efforts must continue to be carried out by the local government.

\section{Conclusion}

The mainshock of Padanglawas earthquake on April 30, 2020, had Mw 5.0, the moment tensor inversion results obtained NP1: 100.1/88/7.5 and NP2: 9.9/82.5/178.3. Thus, NP2 is more in line with the dextral mechanism of the Sumatran Fault, also supported by the distribution of dominant aftershocks in the southeast direction. Earthquake mitigation efforts need to be carried out in the Toru Fault and Angkola Fault surrounding areas because the potential for earthquakes in this area is relatively high.

\section{References}

1. Natawidjaja, D. H. (2018). Major Bifurcations, Slip Rates, and A Creeping Segment of Sumatran Fault Zone in Tarutung-Sarulla-SipirokPadangsidempuan, Central Sumatra, Indonesia. Indonesian Journal on Geoscience, 5(2), 137-160.

2. Sieh, K., \& Natawidjaja, D. (2000). Neotectonics of the Sumatran fault, Indonesia. Journal of Geophysical Research: Solid Earth, 105(B12), 28295-28326.

3. Helffrich, G., Wookey, J., \& Bastow, I. (2013). The seismic analysis code: A primer and user's guide. Cambridge University Press.

4. Kikuchi, M., \& Kanamori, H. (1991). Inversion of complex body waves-III. Bulletin of the Seismological Society of America, 81(6), 2335 2350.

5. Yagi, Y., \& Nishimura, N. (2011). Moment tensor inversion of near source seismograms. Bulletin of the International Institute of Seismology and Earthquake Engineering, 45, 133-138.

6. Triantafyllis, N., Sokos, E., \& Ilias, A. (2016). SCISOLA: REAL-TIME MOMENT TENSOR MONITORING FOR SEISCOMP3. Bulletin of the Geological Society of Greece, 50(2), 1120-1129.

7. Weller, O., Lange, D., Tilmann, F., Natawidjaja, D., Rietbrock, A., Collings, R., \& Gregory, L. (2012). The structure of the Sumatran Fault revealed by local seismicity. Geophysical Research Letters, 39(1).

8. Abdel-aal, A. A. K., \& Yagi, Y. (2017). Earthquake source characterization, moment tensor solutions, 
and stress field of small-moderate earthquakes occurred in the northern Red Sea Triple Junction. Geosciences Journal, 21(2), 235-251.

9. Natawidjaja, D. H. (2018, February). Updating active fault maps and sliprates along the Sumatran Fault Zone, Indonesia. In IOP Conference Series: Earth and Environmental Science (Vol. 118, No. 1, p. 012001). IOP Publishing. 